\section{DiscoverSys \\ Published by DiscoverSys \\ Sexual Role and History of Sexual Transmitted Infection as a Risk of HIV Seroconversion among Men who have Sex with Men who Attended Bali Medika Clinic Badung, Bali}

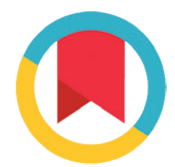

CrossMark

\author{
Ni Putu Diwyami, ${ }^{1 *}$ Anak Agung Sagung Sawitri, ${ }^{1,2}$ Dewa Nyoman Wirawan ${ }^{1,2}$
}

\begin{abstract}
Background and purpose: HIV prevalence among men who have sex with men (MSM) increased from 5\% on 2007 into 12\% on 2011 in Indonesia. High risk sex behaviour was reported associated with HIV seroconversion, however reported research publication about risk factors of HIV seroconvertion among MSM is limited in Indonesia. This study aims to investigate risk factors of HIV seroconversion among MSM.

Methods: Case control study was conducted based on cohort data of MSM who repeatedly visited Bali Medika Clinic, Kuta, Badung, Bali Province between 2011-2015. HIV Seroconversion was defined as MSM with a negative HIV status at the beginning of the observation and

became positive on the next visit. Data were analyzed using Kaplan Meier and logistic regression method.

Results: Median time of HIV seroconversion among MSM was 458 days or 1.2 years (IQR=224-699). Multivariate analysis showed that risk factors of HIV seroconversion were repeated STD's experience in the last 6 months with $A 0 R=8.33$ (95\%Cl: 1.77-89.81); had 1 time STD's history in last 6 months with $\mathrm{AOR}=1.91$ (95\%Cl: $1.15-3.83)$; receptive sexual relationship in the last 6 months with $A O R=3,45(95 \% \mathrm{Cl}: 1.68-7.11)$; and versatile sexual relationship in the last 6 months with $A O R=2.37$ ( $95 \% \mathrm{Cl}: 1.09-5.13$ ). Conclusion: STD's experience, receptive and versatile sexual role are risk factors of HIV seroconversion among MSM.
\end{abstract}

\title{
Sexual Role dan Riwayat Infeksi Menular Seksual Sebagai Risiko Serokonversi HIV pada Laki Seks dengan Laki yang Berkunjung di Klinik Bali Medika Badung, Bali
}

\section{ABSTRAK}

Latar belakang dan tujuan: Di Indonesia terjadi peningkatan prevalensi HIV pada laki-laki yang berhubungan seks dengan laki-laki (LSL) dari 5\% di tahun 2007 menjadi 12\% di tahun 2011. Perilaku seksual berisiko dilaporkan meningkatkan risiko terjadinya serokonversi HIV, namun informasi tersebut belum banyak tersedia pada LSL di Indonesia. Penelitian ini bertujuan untuk mengetahui faktor risiko serokonversi HIV pada LSL.

Metode: Penelitian case control dilakukan menggunakan data kohor LSL yang melakukan tes HIV berulang di Klinik Bali Medika, Kuta, Kabupetan Badung, Provinsi Bali tahun 2011-2015. Serokonversi HIV didefinisikan pada LSL yang masih memiliki status HIV negatif di awal pengamatan dan mengalami perubahan status menjadi positif pada kunjungan tes berikutnya. Analisis data dilakukan dengan Kaplan Meier dan metode regresi logistik.

Hasil: Sebanyak 50\% kohor LSL mengalami serokonversi setelah 458 hari atau 1,2 tahun (IQR=224-699). Analisis multivariat menunjukkan bahwa faktor risiko terjadinya serokonversi HIV adalah riwayat IMS berulang dalam 6 bulan terakhir dengan $\mathrm{AOR}=8,33$ (95\%Cl: 77-89,81); pernah 1 kali mengalami IMS dalam 6 bulan terakhir dengan $A 0 R=1,91$ (95\%(l: 1,15-3,83); perilaku peran seks reseptif dalam 6 bulan terakhir dengan $A 0 R=3,45$ ( $95 \% \mathrm{Cl}: 1,68-7,11)$; dan perilaku peran seks versatil dalam 6 bulan terakhir dengan AOR=2,37 (95\%Cl: 1,09-5,13).

Simpulan: Riwayat IMS serta perilaku sexual role reseptif dan versatil dijumpai sebagai faktor risiko terjadinya serokonversi HIV pada LSL.
${ }^{2}$ Department of Community and Preventive Medicine Faculty of Medicine Udayana University

${ }^{*}$ Correspondence to:

Ni Putu Diwyami, Public Health Postgraduate Program Udayana University

amie.amuro@gmail.com
Kata kunci: serokonversi, LSL, VCT, sexual role, Bali

Kutip artikel ini: Diwyami, N.P., Sawitri, A.A.S., Wirawan, D.N. 2016. Sexual Role dan Riwayat Infeksi Menular Seksual Sebagai Risiko Serokonversi HIV pada Laki Seks dengan Laki yang Berkunjung di Klinik Bali Medika Badung, Bali. Public Health and Preventive Medicine Archive 4(1): 10-16. D0l:10.15562/phpma.v4i1.50 


\section{PENDAHULUAN}

Secara global dilaporkan bahwa prevalensi HIV pada lelaki seks dengan lelaki (LSL) tahun $2012 \mathrm{di}$ Amerika, Asia Tenggara, Asia Selatan dan kawasan Sub-sahara Afrika berkisar antara 14-18\%. ${ }^{1}$ Berdasarkan hasil survei di beberapa kota di Indonesia dilaporkan bahwa terjadi peningkatan prevalensi HIV pada LSL dari 5\% di tahun 2007 menjadi 12\% di tahun 2011.,3 Sementara itu estimasi Kementerian Kesehatan (Kemenkes) tahun 2012 menunjukkan bahwa jumlah populasi LSL di Indonesia adalah sekitar 1 juta orang dan jumlah LSL HIV positif sekitar 80.000 orang. ${ }^{4}$ Sedangkan untuk Provinsi Bali jumlah populasi LSL diperkirakan sekitar 14.000 orang dan yang HIV positif sekitar 950 orang atau sekitar $7 \%{ }^{4}$ Jumlah orang dengan HIV/AIDS (odha) pada LSL di Bali terlihat meningkat setelah dibukanya layanan IMS dan tes HIV untuk LSL di Bali yaitu di Klinik Bali Medika dan Yayasan Kerti Praja. Hal ini terlihat dari laporan Dinas Kesehatan Provinsi Bali tentang jumlah kumulatif odha yang menunjukkan ada kecenderungan peningkatan jumlah kasus pada LSL. ${ }^{5}$

Perilaku seksual berisiko dilaporkan meningkatkan risiko terjadinya serokonversi HIV. Beberapa penelitian melaporkan hubungan seks anal yang tidak aman pada LSL merupakan faktor risiko terinfeksi HIV. Semakin tinggi frekuensi LSL melakukan perilaku seks anal yang tidak aman maka risiko terjadinya serokonversi HIV juga semakin tinggi. ${ }^{6,7}$ Risiko infeksi HIV yang tinggi pada LSL sering dikaitkan dengan peran dalam hubungan seksual yang berisiko tinggi terinfeksi HIV, khususnya pada pasangan yang berperan sebagai reseptif. ${ }^{8}$ Penelitian lain juga melaporkan bahwa terjadinya serokonversi HIV berhubungan dengan riwayat infeksi menular seksual (IMS) sebelumnya, seperti sifilis dan gonore. ${ }^{9}$ Beberapa penelitian lain juga melaporkan bahwa faktor sosiodemografi berhubungan dengan serokonversi HIV pada LSL. ${ }^{10-13}$ Penelitian terpublikasi tentang faktor risiko serokonversi HIV pada LSL di Indonesia khususnya di Bali masih sangat terbatas. Penelitian ini dilakukan untuk mengetahui faktor risiko terkait serokonversi HIV dengan mempergunakan data sekunder yang tersedia di Klinik Bali Medika.

\section{METODE}

Penelitian case control dilakukan pada 82 kasus dan 176 kontrol di Klinik Bali Medika, Kuta, Kabupaten Badung, Provinsi Bali. Klinik ini berdiri pada akhir tahun 2011 dan merupakan klinik khusus LSL di Bali yang memberikan pelayanan IMS dan
HIV/AIDS. Hingga saat ini terdapat sekitar 4.000 kunjungan LSL yang mengakses layanan konseling maupun testing di klinik tersebut. Dalam sebulan rata-rata klinik ini melayani sekitar 100 LSL dan terdapat sekitar $10-15 \%$ LSL yang terdiagnosis HIV positif dari 100 orang yang melakukan VCT tiap bulannya. Populasi kasus adalah seluruh LSL yang mengalami serokonversi HIV di Klinik Bali Medika selama tahun 2011-2015 dan memiliki rekam medik, sedangkan populasi kontrol adalah LSL yang pernah melakukan VCT berulang selama tahun 2011-2015 dan masih memiliki status HIV negatif. Pemilihan kontrol dilakukan secara tidak random dari daftar kunjungan pasien dengan syarat memiliki tahun memulai VCT yang sama dengan kasus, pernah melakukan tes HIV minimal dua kali, serta memiliki status HIV negatif hingga akhir pengamatan.

Variabel bebas meliputi kondisi sosiodemografi pada awal pengamatan (umur, status pernikahan, status pekerjaan, dan tingkat pendidikan), perilaku seksual berisiko yaitu memiliki pasangan seks perempuan, peran dalam hubungan seks anal (sexual role), dan penggunaan kondom, riwayat infeksi menular seksual (IMS), serta frekuensi tes HIV. Data tentang variabel-variabel ini diperoleh dari rekam medik pasien di Klinik Bali Medika.

Data dianalisis secara univariat, bivariat, dan multivariat menggunakan Stata. Variabel yang memiliki tingkat kemaknaan $\mathrm{p}<0,25$ dalam analisis bivariat dimasukkan ke dalam model multivariat untuk memperoleh nilai adjusted OR (AOR). Data missing pada studi dikeluarkan sehingga tidak mempengaruhi hasil analisis. Penelitian ini telah mendapatkan kelaikan etik dari Komisi Etik Fakultas Kedokteran Universitas Udayana/Rumah Sakit Umum Pusat.

\section{HASIL}

Pada Tabel 1 disajikan insiden serokonversi HIV pada LSL yang berkunjung di Klinik Bali Medika. Hasil penelitian menunjukkan dari 1.847 LSL yang pernah melakukan tes HIV di Klinik Bali Medika selama tahun 2011-2015, sebanyak 370 diantaranya pernah melakukan tes HIV berulang dengan status HIV negatif, sedangkan 82 orang ditemukan dengan serokonversi HIV. Analisis Kaplan Meier pada kelompok LSL yang mengalami serokonversi menunjukkan bahwa 50\% kohor LSL mengalami serokonversi setelah 458 hari atau 1,2 tahun (IQR=224-699) sejak pertama kali melakukan tes di Klinik Bali Medika. Serokonversi HIV pada penelitian ini adalah 18,14 per 100 orang bulan dan ditemukan adanya peningkatan insiden dalam 6 bulan.

Pada Tabel 2 disajikan insiden serokonversi HIV berdasarkan faktor risiko dalam 6 bulan terakhir. 
Tabel 1 Insiden serokonversi HIV pada LSL yang berkunjung di Klinik Bali Medika

\begin{tabular}{lccc}
\hline Bulan pengamatan & Jumlah serokonversi & Jumlah orang-bulan yang diikuti & Insiden serokonversi per 100 orang-bulan \\
\hline 6 bulan & 14 & 452 & 3,09 \\
$7-12$ bulan & 19 & 438 & 4,33 \\
$13-\geq 18$ bulan & 49 & 419 & 11,69 \\
\hline
\end{tabular}

\section{Tabel 2 Insiden serokonversi HIV berdasarkan faktor risiko dalam 6 bulan terakhir}

\begin{tabular}{|c|c|c|c|}
\hline Karakteristik & Jumlah serokonversi & Jumlah orang-bulan yang diikuti & $\begin{array}{l}\text { Insiden serokonversi } \\
\text { per } 100 \text { orang-bulan }\end{array}$ \\
\hline \multicolumn{4}{|l|}{ Umur } \\
\hline 15-24 tahun & 54 & 298 & 18,68 \\
\hline$\geq 25$ tahun & 28 & 154 & 18,18 \\
\hline \multicolumn{4}{|c|}{ Sexual role dalam 6 bulan terakhir } \\
\hline Insertif & 26 & 144 & 18,05 \\
\hline Reseptif & 34 & 187 & 18,18 \\
\hline Versatil & 22 & 121 & 18,18 \\
\hline \multicolumn{4}{|c|}{ Riwayat IMS dalam 6 bulan terakhir } \\
\hline Sifilis & 12 & 67 & 17,91 \\
\hline Proktitis & 6 & 33 & 18,18 \\
\hline Gonorea & 1 & 5 & 3,63 \\
\hline Lainnya & 8 & 44 & 18,18 \\
\hline Tidak IMS & 55 & 303 & 18,15 \\
\hline \multicolumn{4}{|c|}{ Penggunaan kondom dalam 6 bulan terakhir } \\
\hline Konsisten & 27 & 149 & 18,12 \\
\hline Tidak konsisten & 55 & 303 & 18,15 \\
\hline Jumlah & 82 & 452 & 18,14 \\
\hline
\end{tabular}

Tabel 3 Komparabilitas kelompok kasus dan kontrol pada kunjungan pertama di Klinik Bali Medika

\begin{tabular}{|c|c|c|c|c|}
\hline \multirow[b]{2}{*}{ Variabel } & \multicolumn{2}{|c|}{ Status HIV } & \multirow[b]{2}{*}{ Total } & \multirow[b]{2}{*}{ Nilai p } \\
\hline & HIV negatif $(n=176)$ & HIV positif $(n=82)$ & & \\
\hline \multicolumn{5}{|l|}{ Agama } \\
\hline Hindu & $24(13,6)$ & $20(24,3)$ & $44(17,0)$ & 0,02 \\
\hline Islam & $100(56,8)$ & $43(52,4)$ & $143(55,4)$ & \\
\hline Kristen & $26(14,7)$ & $14(17,0)$ & $40(15,5)$ & \\
\hline Budha & $4(2,2)$ & $3(3,6)$ & $7(2,7)$ & \\
\hline \multicolumn{5}{|l|}{ Domisili } \\
\hline Denpasar & $99(56,2)$ & $45(54,8)$ & $144(55,8)$ & 0,47 \\
\hline Badung & $66(37,5)$ & $32(39,0)$ & $98(37,9)$ & \\
\hline Kabupaten lainnya & $5(2,8)$ & $4(4,8)$ & $9(3,4)$ & \\
\hline Luar Bali & $4(2,2)$ & $1(1,2)$ & $5(1,9)$ & \\
\hline \multicolumn{5}{|l|}{ Alasan Tes } \\
\hline Merasa berisiko & $169(96,0)$ & $80(97,5)$ & $249(96,5)$ & 0,73 \\
\hline Lainnya ${ }^{*}$ & $7(3,9)$ & $2(2,4)$ & $9(3,4)$ & \\
\hline Pernah tes sebelumnya & $46(26,1)$ & $10(12,2)$ & $56(21,7)$ & 0,01 \\
\hline Pernah mengalami IMS & $75(42,6)$ & $38(46,3)$ & $113(43,8)$ & 0,57 \\
\hline
\end{tabular}




\begin{tabular}{|c|c|c|c|c|}
\hline \multirow[b]{2}{*}{ Variabel } & \multicolumn{2}{|c|}{ Status HIV } & \multirow[b]{2}{*}{ Total } & \multirow[b]{2}{*}{ Nilai p } \\
\hline & HIV negatif $(n=176)$ & HIV positif $(n=82)$ & & \\
\hline \multicolumn{5}{|c|}{ Tahun memulai VCT } \\
\hline 2011 & $29(16,4)$ & $13(15,8)$ & $42(16,2)$ & \multirow{5}{*}{0,68} \\
\hline 2012 & $70(39,7)$ & $34(41,4)$ & $104(40,3)$ & \\
\hline 2013 & $31(17,6)$ & $17(20,7)$ & $48(18,6)$ & \\
\hline 2014 & $42(23,8)$ & $16(19,5)$ & $58(22,4)$ & \\
\hline 2015 & $4(2,2)$ & $2(2,4)$ & $6(2,3)$ & \\
\hline \multicolumn{5}{|c|}{ Frekuensi tes } \\
\hline 2-3 kali & $70(39,7)$ & $52(63,4)$ & $122(47,2)$ & \multirow{2}{*}{0,00} \\
\hline$>3$ kali & $106(60,2)$ & $30(36,5)$ & $136(52,7)$ & \\
\hline
\end{tabular}

${ }^{*}$ ingin tahu saja, dirujuk LSM, untuk bekerja

Tabel 4 Analisis bivariat dan multivariat kondisi sosiodemografi, perilaku seks berisiko, dan riwayat IMS terhadap serokonversi HIV

\begin{tabular}{|c|c|c|c|c|c|c|}
\hline \multirow[b]{2}{*}{ Variabel } & \multicolumn{2}{|c|}{ Analisis bivariat } & \multirow[b]{2}{*}{ Nilai p } & \multicolumn{2}{|c|}{ Analisis multivariat } & \multirow[b]{2}{*}{ Nilai p } \\
\hline & $\begin{array}{c}\text { HIV negatif } \\
\text { n (\%) }\end{array}$ & $\begin{array}{c}\text { HIV positif } \\
\text { n (\%) }\end{array}$ & & Adjusted OR & $95 \% \mathrm{Cl}$ & \\
\hline \multicolumn{7}{|l|}{ Sosiodemografi } \\
\hline \multicolumn{7}{|l|}{ Umur } \\
\hline$\geq 25$ tahun & $78(44,3)$ & $28(34,1)$ & & & & \\
\hline 15-24 tahun & $98(55,6)$ & $54(65,8)$ & 0,12 & - & - & - \\
\hline \multicolumn{7}{|l|}{ Status pekerjaan } \\
\hline Tidak bekerja & $18(10,9)$ & $6(8,2)$ & \multirow{2}{*}{0,43} & & & \\
\hline Bekerja & $146(89,0)$ & $67(91,7)$ & & - & - & - \\
\hline \multicolumn{7}{|l|}{ Status pernikahan } \\
\hline Menikah & $3(1,7)$ & $5(6,1)$ & & & & \\
\hline Belum menikah & $172(98,2)$ & $77(93,9)$ & 0,07 & - & - & - \\
\hline \multicolumn{7}{|l|}{ Lama pendidikan } \\
\hline$>9$ tahun & $145(82,3)$ & $67(81,7)$ & \multirow{2}{*}{0,91} & \multirow{2}{*}{-} & \multirow{2}{*}{-} & \multirow{2}{*}{-} \\
\hline$\leq 9$ tahun & $10(5,6)$ & $4(4,8)$ & & & & \\
\hline \multicolumn{7}{|l|}{ Kelompok Risiko } \\
\hline Monoseksual & $149(84,6)$ & $69(84,1)$ & & & & \\
\hline Biseksual & $27(15,3)$ & $13(15,8)$ & 0,91 & - & - & - \\
\hline \multicolumn{7}{|l|}{ Riwayat IMS dalam 6 bulan terakhir } \\
\hline Sifilis & $13(5,0)$ & $12(4,6)$ & 0,07 & - & - & - \\
\hline Kondiloma & $5(2,8)$ & $5(6,10)$ & 0,21 & - & - & - \\
\hline Proktitis & $3(1,7)$ & $6(7,3)$ & 0,03 & - & - & - \\
\hline Gonore & $1(0,5)$ & $1(1,2)$ & 0,55 & - & - & - \\
\hline \multicolumn{7}{|l|}{ Frekuensi IMS } \\
\hline Tidak IMS & $147(83,5)$ & $55(67,0)$ & & (ref) & & \\
\hline 1 kali IMS & $27(15,3)$ & $24(29,2)$ & 0,01 & 1,91 & $1,15-3,83$ & 0,03 \\
\hline 2 kali IMS & $2(1,1)$ & $3(2,6)$ & & 8,33 & $1,77-89,8$ & 0,04 \\
\hline \multicolumn{7}{|l|}{ Sexual role dalam 6 bulan terakhir } \\
\hline Insertif & $66(37,5)$ & $17(20,7)$ & & (ref) & & \\
\hline Reseptif & $38(21,5)$ & $34(41,4)$ & & 3,45 & $1,68-7,11$ & 0,00 \\
\hline Versatil & $36(20,4)$ & $22(26,8)$ & 0,00 & 2,37 & $1,09-5,13$ & 0,02 \\
\hline Tidak menggunakan kondom pada seks terakhir & $95(53,9)$ & $53(64,6)$ & 0,09 & - & - & - \\
\hline
\end{tabular}


Insiden ditemukan lebih tinggi pada LSL kelompok umur 15-24 tahun (18,68 per 100 orang-bulan) dan lebih tinggi ditemukan pada LSL yang berperan seks secara reseptif maupun versatil $(18,18$ per 100 orang bulan). Insiden juga ditemukan lebih tinggi pada LSL yang pernah mengalami proktitis dalam 6 bulan terakhir (18,18 per 100 orang-bulan). Dibandingkan dengan LSL yang konsisten menggunakan kondom dalam 6 bulan terakhir, insiden pada LSL yang tidak konsisten menggunakan kondom ditemukan sedikit lebih tinggi yakni sebesar 18,15 per 100 orang-bulan.

Tabel 3 menunjukkan komparabilitas kelompok kasus dan kontrol pada saat kunjungan pertama di Klinik Bali Medika dan terlihat bahwa telah ada kemiripan antara kelompok kasus dan kontrol berdasarkan domisili, alasan melakukan tes sebelumnya, riwayat IMS, serta tahun memulai VCT.

Pada Tabel 4 disajikan hasil analisis bivariat dan multivariat antara variabel bebas dengan kejadian serokonversi HIV. Variabel-variabel dengan nilai $\mathrm{p}<0,25$ dimasukkan ke dalam analisis multivariat yaitu variabel umur, status pernikahan, riwayat sifilis, kondiloma, proktitis, frekuensi IMS dalam 6 bulan terakhir, perilaku sexual role dalam 6 bulan terakhir dan tidak menggunakan kondom pada seks terakhir.

Variabel yang dijumpai bermakna sebagai faktor risiko serokonversi HIV pada LSL yang melakukan tes berulang di Klinik Bali Medika adalah mengalami IMS dalam 6 bulan terakhir serta memiliki perilaku seksual secara reseptif dan versatil dalam 6 bulan terakhir. Risiko serokonversi HIV ditemukan 8,33 kali (AOR=8,33; 95\%CI: 1,15-3,83) lebih tinggi pada kelompok LSL yang mengalami IMS berulang dan berisiko 1,91 kali (AOR=1,91; 95\%CI: 1,15-3,83) lebih tinggi pada LSL yang pernah mengalami IMS dibandingkan dengan LSL yang tidak mengalami IMS dalam 6 bulan terakhir. Risiko untuk mengalami serokonversi HIV juga ditemukan 3,45 kali (AOR=3,45; 95\%CI: 1,68$7,11)$ lebih tinggi pada LSL yang berperilaku seks secara reseptif dan ditemukan 2,37 kali $(\mathrm{AOR}=2,37$; 95\%CI: 1,09-5,13) lebih tinggi pada LSL yang berperilaku seks secara versatil dibandingkan dengan LSL yang berperilaku seks secara insertif dalam 6 bulan terakhir.

\section{DISKUSI}

Penelitian ini menunjukkan bahwa separuh LSL mengalami serokonversi HIV pada 1,2 tahun sejak VCT pertama di klinik ini. Serokonversi HIV pada penelitian ini belum tentu merupakan insiden terinfeksi HIV karena serokonversi dalam penelitian ini ditentukan dari waktu kunjungan LSL untuk tes HIV ulang berikutnya. Dengan demikian serokonversi ini adalah perkiraan dari insiden HIV, namun belum dapat diketahui dengan jelas, kapan perubahan status HIV tersebut sebenarnya terjadi.

Hubungan seks anal menjadi perilaku seks paling berisiko pada LSL. Kegagalan dalam penggunaan kondom juga lebih tinggi pada seks anal dibandingkan dengan seks per vaginal. ${ }^{14}$ Penelitian ini menemukan serokonversi HIV lebih tinggi pada LSL yang berperilaku seks secara versatil dibandingkan dengan LSL yang berperilaku seks secara insertif dalam 6 bulan terakhir. Demikian pula serokonversi HIV ditemukan paling tinggi pada LSL yang berperilaku seks secara reseptif dibandingkan dengan LSL yang berperilaku seks secara insertif dalam 6 bulan terakhir. Kemungkinan hal ini yang memudahkan HIV untuk masuk kedalam tubuh. LSL yang berperan sebagai insertif dalam hubungan seks anal memiliki risiko lebih rendah terinfeksi HIV. ${ }^{13}$ Temua ini konsisten dengan penelitian yang dilakukan di Brasil dan Kanada, bahwa LSL yang melakukan hubungan seks anal tidak aman secara reseptif berisiko paling tinggi terinfeksi HIV dibandingkan LSL yang berperan insertif maupun versatil. Pada penelitian yang sama juga dilaporkan bahwa LSL yang melakukan hubungan seks anal tidak aman dengan pasangan serodiskordan merupakan faktor risiko utama untuk mengalami serokonversi HIV dan risiko terbesar pada hubungan seks tidak aman secara reseptif. ${ }^{15,16}$

Analisis data perilaku sexual role dengan kelompok umur menunjukkan bahwa LSL yang berusia 15-24 tahun memiliki kecenderungan berperan reseptif, sedangkan LSL usia $\geq 25$ tahun memiliki kecenderungan berperan insertif, sedangkan peran versatil memiliki proporsi hampir seimbang pada kedua kelompok umur tersebut. Meskipun pada penelitian ini tidak ditemukan adanya hubungan yang signifikan antara umur LSL dengan serokonversi HIV, namun beberapa hasil penelitian melaporkan bahwa terdapat perbedaan risiko LSL usia muda dan tua. ${ }^{17,18}$ Hasil ini dapat dibandingkan dengan penelitian kualitatif yang dilakukan terhadap LSL usia muda di Amerika dimana ditemukan bahwa LSL yang berperan secara insertif dianggap lebih mampu untuk terbuka dalam memilih pasangan seksualnya serta mempertahankan identitas heteroseksual mereka. ${ }^{19}$ Kemungkinan penjelasan akan hal tersebut adalah perbedaan usia antar pasangan seksual pada kalangan ini dimana pasangan seks yang memiliki usia lebih tua cenderung memiliki status sosial ekonomi yang lebih tinggi dan pengalaman seks yang lebih banyak, sehingga LSL yang berperan secara reseptif selama melakukan hubungan seks anal tidak aman lebih ditujukan kepada LSL usia muda dan dianggap lebih banyak memberikan kontribusi terhadap peningkatan insiden HIV. ${ }^{19}$ 
Penelitian ini menemukan serokonversi HIV lebih berisiko pada LSL yang pernah mengalami IMS dan IMS berulang dalam 6 bulan terakhir dibandingkan dengan LSL yang tidak mengalami IMS dalam 6 bulan terakhir. Beberapa penelitian juga melaporkan bahwa IMS berhubungan terhadap peningkatan risiko penularan $\mathrm{HIV}^{20,21}$ Data surveilans di New York mengindikasikan bahwa LSL juga mempunyai risiko dua kali lipat untuk terinfeksi IMS dan infeksi rektal disertai dengan bakteri IMS pada hubungan seks anal tanpa kondom dan menjadi salah satu faktor risiko penularan $\mathrm{HIV}^{21}$ Penelitian yang dilakukan di Amerika juga melaporkan bahwa LSL yang pernah mengalami infeksi rektal berulang dalam 2 tahun terakhir berisiko untuk mengalami serokonversi $\mathrm{HIV}^{21}$ Banyak penelitian terkait juga menyatakan hal yang sama dimana LSL yang sebelumnya pernah mengalami IMS (sifilis, gonore, genital ulcer, maupun infeksi rektal lainnya) akan lebih berisiko untuk tertular virus HIV. ${ }^{20-22}$ Infeksi rektal seperti proktitis tidak dapat diabaikan mengingat perilaku seks tanpa kondom yang sering dilakukan oleh LSL adalah perilaku seks anal berisiko dimana infeksi rektal dapat meningkatkan kerentanan biologis terhadap infeksi HIV melalui erosi epitel dan perubahan dalam pertahanan kekebalan tubuh. ${ }^{13,21}$ Beberapa jenis infeksi pada rektal tidak menunjukkan gejala, dan karena itu kegiatan screening secara rutin menjadi sangat penting untuk menurunkan infeksi rektal termasuk infeksi HIV. Korelasi antara jenis dan frekuensi IMS menunjukkan bahwa kegiatan screening dan pengobatan IMS sangat perlu mendapatkan perhatian khusus sebagai upaya untuk mengontrol penularan infeksi HIV pada LSL. ${ }^{12-23}$

Pada penelitian ini tidak semua LSL ditemukan memiliki orientasi seks homoseksual dimana sebanyak $15,58 \%$ LSL dengan status HIV positif memiliki orientasi seks biseksual. Hasil analisis tidak menemukan adanya hubungan yang signifikan antara orientasi seks terhadap serokonversi HIV dan beberapa penelitian serupa tidak menemukan hasil yang konsisten. ${ }^{24,25}$ Kondisi ini perlu diwaspadai khususnya pada negara berkembang dimana LSL akan cenderung menutupi status homoseksualnya dengan tetap memiliki pasangan seks perempuan. Hal ini akan menyebabkan risiko penularan infeksi HIV tidak hanya terjadi antara sesama laki-laki melainkan juga pada pasangan seks perempuannya dan anak-anak mereka di masa depan. ${ }^{26}$

Dalam penelitian ini dijumpai bahwa penggunaan kondom dalam hubungan seks anal pada seks terakhir sangat rendah, dimana pada kasus $(64,6 \%)$ dan kontrol (53,9\%) ditemukan tidak menggunakan kondom pada seks terakhir. Sebesar 65,06\% pada kedua kelompok berperan insertif meskipun dalam hasil analisis tidak ditemukan hubungan yang siginifikan terhadap penggunaan kondom dengan kejadian serokonversi HIV. Hasil ini tidak sejalan dengan penelitian lainnya yang menyatakan bahwa LSL yang tidak konsisten menggunakan kondom lebih berisiko untuk mengalami serokonversi HIV dibandingkan dengan LSL yang menggunakan kondom secara konsisten. ${ }^{15,25}$ Berdasarkan hasil penelitian ini bahwa penggunaan kondom masih rendah pada hubungan seks terakhir. Temuan ini bisa menjadi bahan masukan bagi penentu kebijakan dan pemberi layanan kesehatan dalam melakukan konseling dan edukasi untuk tetap melakukan intervensi perubahan perilaku berisiko seperti negosiasi penggunaan kondom yang benar dengan pasangan seksualnya.

Keterbatasan penelitian adalah dengan menggunakan data sekunder sehingga pencatatan data yang tidak lengkap adalah salah satu sumber bias penelitian. Selain itu kemungkinan adanya selection bias, yaitu dalam pemilihan kelompok kontrol yang dilakukan secara tidak random. Penelitian ini hanya dilakukan pada satu klinik dan wilayah yang sangat terbatas, sehingga tidak bisa digeneralisasi pada populasi yang lebih luas.

\section{SIMPULAN}

Hasil penelitian menunjukkan bahwa 50\% kohor LSL mengalami serokonversi setelah 458 hari atau 1,2 tahun (IQR=224-699). Riwayat IMS serta perilaku sexual role reseptif dan versatil dijumpai sebagai faktor risiko terjadinya serokonversi HIV pada LSL. Serokonversi HIV pada LSL ditemukan lebih berisiko pada LSL yang berperilaku seksual reseptif dan dominan dijumpai pada LSL usia muda.

\section{UCAPAN TERIMA KASIH}

Pada kesempatan ini peneliti mengucapkan terima kasih kepada seluruh staf Klinik Bali Medika.

\section{DAFTAR PUSTAKA}

1. Beyrer, C, et al. Global Epidemiologi of HIV Infection in men who have sex with men. Lancet; 2012; 380:367-377.

2. Kemenkes RI. STBP: Surveilans Terpadu Biologis dan Perilaku Tahun 2011. Jakarta: Ditjen PP \& PL Kemenkes RI; 2011.

3. Kemenkes RI.. STBP: Surveilans Terpadu Biologis dan Perilaku Tahun 2011. Jakarta: Ditjen PP \& PL Kemenkes RI; 2007.

4. Kemenkes RI. Estimasi Jumlah Populasi Kunci per Provinsi Tahun 2012. Jakarta: Ditjen PP \& PL Kemenkes RI; 2012.

5. Dinas Kesehatan Provinsi Bali. Laporan Kumulatif Kasus HIV/AIDS di Provinsi Bali. Denpasar: Dinkes Provinsi Bali; 2016. 
6. Pilcher CD, Tien HC, Eron JJ Jr, et al. 2004. Brief but efficient: acute HIV infection and the sexual transmission of HIV. J Infect Dis; 2004; 189:1785-1792.

7. Golden MR, Wood RW. STD/HIV Screening Guidelines for Men Who Have Sex with Men (MSM). Seattle, WA: Public Health-Seattle and King County; 2005.

8. Koblin, BA., et al. High Prevalence of HIV infection among young men who have sex with men in New York City. AIDS; 2000;14:1793-1800.

9. Mimiaga, MJ, et al. Alcohol Use and HIV Sexual Risk among MSM in Chennai, India. Int J STD AIDS; 2011; 22(3):121-125

10. Jin, Fengyi, et al. Anal Sexually Transmitted Infections and Risk of HIV Infection in Homosexual Men. J Acquir Immune Defic Syndr; 2010; 53:144-149.

11. Schwarcz, Sandra, et al. Prevalence of HIV Infection and Predictors of High Transmission Sexual Risk Behaviors among Men Who Have Sex With Men. American Journal of Public Health; 2007; 97(6).

12. Angelica, et al. Differences in Risk Behaviors and Partnership Patterns Between Younger and Older Men Who Have Sex With Men in New York City. JAIDS Journal of Acquired Immune Deficiency Syndromes; 2011; 58(4):417-423.

13. Li, Doliang, et al.HIV incidence among men who have sex with men in Beijing: a prospective cohort study. Availbale at: http://bmjopen.bmj.com/ Access: 13 December 2015 Published by group.bmj.com

14. Zhou, Chao, et al. 2012. Anal Sex Role, Circumcision Status, and HIV Infection Among Men Who Have Sex with Men in Chongqing, China; 2012.

15. Koblin, BA, et al.. Risk factors for HIV infection among men who have sex with men. AIDS; 2006, 20:731-739.

16. Campos, MJ, et al.. HIV incidence among MSM in Portugal as a matter of Risk Management. JAIDS; 201.

17. Craib KJ, Meddings DR, Strathdee SA, et al. Rectal gonorrhoea as an independent risk factor for HIV infection in a cohort of homosexual men. Genitourin Med; 1995; 71:150-154.

18. Liu H, Yang H, Li X, et al. Men who have sex with men and human immunodeficiency virus/sexually transmitted disease control in China. Cell Res; 2005; 15:858-864.
19. Pathela, et al. HIV incidence among men with and without sexually transmitted rectal infections: estimates from matching against an HIV case registry. Clinical Infectious Diseases Advance; 2013.

20. Lavoie, E, et al. Determinants of HIV Sero- conversion among Men Who Have Sex With Men Living in a Low HIV Incidence Population in the Era of Highly Active Antiretroviral Therapie. Sexually Transmitted Diseases; 2008; 35(1):25-29.

21. Cunha, CB, et al. 2014. Unprotected sex among men who have sex with men living with HIV in Brazil: a cross-sectional study in Rio de Janeiro. BMC Public Health; 2014; 14:379.

22. Van Tieu, Hong, et al.. Anal Sex Role Segregation and Versatility Among Men Who Have Sex With Men: EXPLORE Study. JAIDS; 2013; 64:121-125.

23. Yang, Haitao, et al. HIV Incidence and Associated Factors in a Cohort of Men Who Have Sex With Men in Nanjing, China. Sexually Transmitted Diseases; 2010 37(4).

24. Choi KH, Diehl E, Guo Y, et al. High HIV risk but inadequate prevention services for men in China who have sex with men: An ethnographic study. AIDS Behav; 2002; 6:255-266

25. Rebecca F, et al. HIV transmission risk through anal intercourse: systematic review, meta-analysis and implications for HIV prevention. International Journal of Epidemiology; 2010; 39:1048-1063 doi: 10.1093/ije/dyq057

26. Hall, et al. Racial/Ethnic and Age Disparities in HIV Prevalence and Disease Progression Among Men Who Have Sex With Men in the United States. Am J Public Health; 2007; 97:1060-1066

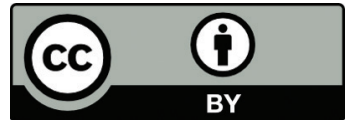

This work is licensed under a Creative Commons Attribution 